\title{
Gadamer's Philosophical Hermeneutics: Investigating the Nexus between Culture and African Philosophy
}

\author{
Ikechukwu Onah \\ http://dx.doi./org/10.4314/ujah.v20i2.3
}

\begin{abstract}
This article attempts to uncover a foundational drive in Gadamer's philosophical hermeneutics and its importance in steeping the tension of the philosophical link of culture and African Philosophy. In his work Gadamer presents culture as the foundation of philosophy. Okere rising from the latter posits that hermeneutics is the mediator between culture and African philosophy. The polemical argument of the rationality of African philosophy though interwoven with skeptical epistemological assumptions which increasingly emphasizes in the ethno decade-long debate is aggregated in mediating stance of hermeneutics as adduced by Okere and other notable African scholars. This article shows that in his most popularity oriented epistemological work, Gadamer did not mute the obstacles that epistemic uncertainty poses to the quest for mere ethno dimension in the light of critical ratiocination in order to avoid acceptance of views without examination. This article pursues this mediating strategy not just for rhetorical but also for a substantive reason on the rational foundation of African Philosophy against the nauseating position that African philosophy is mere cultural beliefs.
\end{abstract}

Keywords: Hermeneutics, Culture and Mediation 


\section{Introduction}

There have been a lot of controversies on the meaning and nature of African philosophy. This led to four major trends known today in African Philosophy. These trends include: Ethno philosophy, philosophical sagacity, Nationalist and ideological philosophy and Professional philosophy. The Ethno philosophers were interested in making philosophy out of myths, folklores, and cultures of Africans. They viewed philosophy as a communal thought rather than a logical view of an individual. They tried to link the present with the past. The philosophical sagacity groups are of the view that the wise sayings of the sages in Africa are embedded in philosophy. They also hold the view that literacy is not a prime standard for philosophizing.

The Nationalist philosophers are of the view that Africans having been dehumanized by colonialism should evolve their own concept and theory of socio-political life that can stand as African oriented and for the total emancipation of Africans. The professional philosophers (mainly the contemporary African thinkers) are of the view that philosophy is a universal discipline that is embedded in a universal method and principles of approach. They maintain that philosophy is not twisted by cultural peculiarities and the subject matter is the same in all traditions. Hence, it is critical ratiocinations of an individual and not a communal view of thought that does not qualify to be a philosophy. Many African writers in a bid to defend African philosophy argued that philosophy has nothing to do with academic exponent of the people. They posit that philosophy is a rational activity which involves rational beings. Aristotle says that it's by wonder that man philosophize. Hence, the bewilderment 
posed by the universe surrounded by their experience propelled the early Africans to question and philosophize which resulted in many principles and beliefs.

Amongst all the debates and pursuit to fashion out what actually should be called African philosophy, it is pertinent to posit what really is the criterion to designate what qualifies as African philosophy so as to alienate it from non-philosophy. It is the scope of this work to resolve these debates through the mediation of hermeneutics as espoused by Hans George Gadamer which later became the bedrock of positions of contemporary African philosophers. Though most of the contemporary African philosophers agreed that philosophy can erupt from culture through the mediation of hermeneutics, some of them disagree that philosophy is not only an "individual enterprise" (Oguejiofor, 2001 , p. 118) but also a communal thought. There is also disagreement among some African thinkers on primacy of conceptualization, logic and method as what designates a work philosophy. We shall in this work attempt to resolve these debates.

\section{Dialoguing between Culture and Africans Philosophy through Hermeneutics}

Hermeneutics is the foundational approach to arriving at a philosophy. Sequel to the conditions that surround the foundation of African philosophy, hermeneutics being a philosophical tool has the potential to investigate into what can qualify as reasoned thought and what does not. Amongst the works of Hermeneutics is to interpret what the grounds are on which beliefs are held and what grounds are good grounds (Schwandt,2001,p.112). Philosophy is not the same as culture and tradition of people but philosophy cannot be totally alienated from culture and traditions. Hence, philosophy grows from culture and traditions. Culture and 
tradition cannot in itself germinate into philosophy but within the context of hermeneutics. By application of philosophical hermeneutics onto culture, symbols poetry, songs, and general tradition of a people, an individual can arise a philosophy.

Salient among the concepts developed by Gadamer central to his philosophical hermeneutics are prejudice and tradition. Hence, Gadamer in attempt to separate prejudice from the everyday usage says we do not know in advance which prejudice are worth preserving and which should be rejected. Thus, prejudice free knowledge is not possible. This is in opposition to Descartes dream of razing to the ground all beliefs that are not clear and distinct which for Gadamer is a move of deception that would entail ridding oneself of the very language that allows one to formulate doubt in the first place. To further understand the nexus between these two salient principles of Gadamer's hermeneutics and its meditative role we must examine the role Gadamer assigns to tradition.

Tradition is a term he developed beyond its common meaning. To posit as Gadamer does, that one can never escape from one's tradition does not mean he is insisting we endorse all traditions writ large. Gadamer is not espousing a conservative approach to traditions that blindly affirm the whole of a tradition and leaves one without recourse to critique it. For Gadamer, accepting the fact that we can never entirely reflect oneself out of tradition does not mean that one cannot change and question one's tradition. Here, it means that in as much as tradition serves as the condition of one's knowledge, the background that instigates all inquiry, "one can never start from a tradition - free - place". Culture and tradition are what gives one a question or interest to begin with while philosophizing. However, all successful efforts to 
enliven a tradition require changing it so as to make it relevant for the current context.

In other words, the importance of the terms tradition and by extension culture for Gadamer's hermeneutics lies in the way it indicates the active nature of understanding that produces something new. Tradition thus hands down certain interests, questions and problems that incite knowledge through hermeneutics. For an inquirer, tradition is provocative and not retrogressive. Gadamer did not affirm blind and passive imitation of tradition or to see tradition in itself a philosophy but to show how making tradition and culture our own means a critical and creative hermeneutic approach to it, which results in bringing out philosophical concepts and principles. When Gadamer talks about effective history, he talks about what lies behind tradition and history; what is around present culture and society and what is before - expectations directed at the future. Rising from Gadamer's thought, it is only within the context of hermeneutics that culture and traditions can give birth to philosophy. Thus, Hermeneutic approach to African culture, traditions, symbols, poetry e.t.c gives birth to African philosophy.

Many attempts to posit what can be designated as African philosophy in the past were rejected by some contemporary writers as uncritical and works that lack rational foundation. The latter also condemn the ethno-philosophical postulation that African philosophy includes the communal views and poetry of earlier Africans. Some contemporary thinkers like Okere rejected the communal view. He argues that philosophy differs from cultural or community world views of the Africans, though such views constitute the foundation on which African philosophy is built. Okere went further to say that philosophy is an individual's effort at critically, consistently and coherently achieving self 
understanding within the context of his culture. Hence, culture and tradition of a people are deposits of raw materials for philosophizing. Okere succinctly posits that Culture as such, with all its manifestations - proverbs, myth, literature, folklore, and religion are not philosophy. Philosophy arises from culture and the mediation between the two is the process of hermeneutics, which consists in the interpretation of the symbols of the culture in question (Hooking, 1958, p.6).

Here like Gadamer, the contemporary African thinkers emphasizes on critical and uncompromising interpretation of what should be taken as philosophy and what should not and a method to attain it. Philosophy as a discipline has no unilateral definition but it possesses some traits that are part and parcel of any knowledge called philosophy or philosophical. Thus, such knowledge production to qualify as philosophy it must be patterned along critical, coherent, and rational inquiry.

Every philosophy evolved from a tradition as Gadamer posits and going by his philosophical Hermeneutics, African philosophy evolves from hermeneutic approach to African cultures, myths, fables, proverbs, legends, songs, poetry and symbols. These materials for philosophy have multiple meanings that can only be understood through hermeneutics. Philosophical hermeneutics as posited by Gadamer unmasks the prejudices and dogmatic prescription associated with traditions and cultures. Nonphilosophy like symbols has multi-vocal meaning; it has literal meaning but point to another meaning which is indirect. For Gadamer, fulfillments of historical process of a particular period remnants of the past are the materials of historical inquiry in the present (Okolo, 1993, P.12). There have been divergent view among some contemporary African thinkers whether there could or there is any work to be called African philosophy. The controversy 
degenerated to tagging all works produced by what is called ethno philosophers as mere literature that does not qualify to be philosophy. The argument are: Mere world views of Africans cannot be tagged as philosophy; wise saying, poetry, symbols and other works of art by legends lacks critical thinking since it does not follow the methods of western logics and methods of ratiocination. Some contemporary thinkers tag the works of the early African writers as non philosophy because they derived their points and materials of inquiring from culture, tradition and fables that are community productions and not individual intellectual exercise. However, the fact that such views by the ancient Africans were not written in a particular text book or documented in written words does not make such works non objects or material for intellectual inquiry.

Since it has been agreed that philosophy is hermeneutic and hermeneutics as Heidegger posits is man's way of being, the earlier Africans were also engaged in philosophy and most of their poetry, views, "legends", symbols, songs, and music must have emanated from hermeneutics (Bilen, 2000, p.9). The fact that the contemporary thinkers cannot lay hands on documents that proved the sequence of questionings and critical analysis by ancient Africans before arriving at their conclusions does not mean that they were alien to philosophy. Thus, Njoku, F.C (2002, P.5) submits that there is no one method of dealing with philosophical problems. Some philosophers are prescriptive while others are descriptive or dialectical and some yet to adopt none of these methods. The point is that the method the early African thinkers used in arriving at their philosophical postulations might not be the same method used by German philosophers or oriental philosophers. Jimbo,S (2002, p.5) corroborates with the latter by his position that what philosophers share is an open mindedness 
which allows for digging up for unacknowledged presuppositions... philosophy is thus understood as a process rather than a fixed body of knowledge ...the problems which philosophy addresses will of course be coloured by specific historical, cultural, geographical peculiarities. One cannot talk about philosophy without talking about the foundation of such philosophy which are cultural, historical and geographical peculiarities. At this juncture, it is vain to ask if African philosophy exist just because the theories and philosophical postulation of the early Africans were not written in a book. A question comes to mind here just as Okonda, asked: The African tradition is the text of our reading but first what is a text? One should not limit the text to a written text. We have to retain the lesson of contemporary hermeneutic theories and extend the sense of a text to include all verbal concatenations and all that offers itself to be read that is to say tradition as a whole. (Okonda, 1991, p.202)

The scope of this work is to show how hermeneutics mediate between culture and African philosophy but for the fact that there are some unresolved issues among some African philosophers, there is need here to debunk Hountondji and some contemporary African thinker's claim that world view cannot be a source of African philosophy because it is communal or collective thought and unwritten. In response to the above position, Aja submits that there is no communal thought in the sense of a group mind because there is no group with a single mind. But from this, it does not follow that we cannot talk intelligently of the cultural beliefs and values of a people arising from their common reflections on their common experience (Aja, 2015,p.1). Aja also goes further to say that 
it is not clear why communal thought in virtue of its being communal cannot be philosophy. It is at least not a selfevident truth that philosophy must always be an individualistic enterprise. It is true historically that western academic philosophy has been individualistic but we should also not forget that such individualized philosophizing has always taken place in bosom of some communal traditions with the presuppositions of certain ideas which are not now easy to trace to anyone individual'. It is denial of the affirmative that we are not all children of our traditions even as we dodge the actuality by "fantasizing individuality". (Aja, 2015,p.10-11)

It is also evident that most of the critical reasoning of the early Africans was preserved in symbols, signs, stories, e.t.c. They might not have preserved their works in written text with the particular patterns as evidenced in western world but it does not presuppose that such works never existed. For Bouah (Niangoran, 1984, p.215) writing is the representation of word and thought by agreed signs. African philosophy existed since time immemorial just as the wisdom and principles which shape their lives has been guiding each generation of Africans. This is because philosophy refers too to the wisdom or principles that shape the lives of a people. Horton (Horton, 1967, p.64) in alliance with the above submission, posit that traditional world-view is by no means static and concedes the existence of creative thinkers who are constantly making readjustment in response to the challenge of new and puzzling situations. 


\section{Significance of Language and History in Hermeneutics}

Ancient philosophers argue that words can conceal and words can revel. It is the mission of Hermeneutics to interpret and bring to human understanding these meaning that are concealed or revealed in words, text or objects. These words or texts are encapsulated in language. Also, by the fact that objects or text of interpretation are situated in history there is important inter play of language and History in Hermeneutic process and methodology. Wacterhauser writes: Hermeneutical theories of understanding argue that all human understanding is never without words and never outside of time On the contrary is what is distinctive about human understanding that it is always in terms of some evolving linguistic framework that has been worked out over time in terms of some historically conditioned set of concerns and practices (Wacterhauser,1986, p.6). But Gadamer, H.G (1996, p.360) amongst other Philosophers emphasized on the important role of history in interpretation. He points that historically informed prejudices are basic condition of understanding. Highlighting his standpoint he posits that a person who believes he is free of prejudices, relying on the objectivity of his procedures and denying that he himself is conditioned by historical circumstances, experiences that power of the prejudices will fail to see what manifest by their light.

Pointing further to the role of language and history in Hermeneutics, Gadamer puts that Language is the universal medium in which understanding occurs in interpreting (Gadamer, 1996,p.389). He further points that in order to be able to express a text's meaning and subject matter; we must translate it into our own language. (Gadamer,1996, p.396). Although an in-depth analysis of these philosophical arguments is beyond the scope of this paper. It is worth noting that Hans Gadamer amongst other 
philosophers, who wrote works on Hermeneutics, is a major thinker in Hermeneutics and that is why he is often cited when issues on Hermeneutics arise.

\section{Critical Approach of Hermeneutics}

So many philosophers that work in Hermeneutic tradition such as Derrida, Jardine, Kearney Habermas and George Gadamer used critical approach in their bid to positing the procedures for human understanding of text and objects in historical review. The critical approach by philosophical Hermeneutics separates it from Exegesis. Thus, Jardine, D ( 1999,p.116) asserts that an interest in tradition and ancestry does not require the repetition of traditions. Rather, Hermeneutics incites the particularities and intimacies of our lives to call these traditions to account, compelling them to bear witness to the lives we are living. In corroboration to critical approach to Hermeneutics, Gadamer, H.G (1976, p.94) posits that hermeneutics exercises a self-criticism of thinking consciousness, a criticism that translates all its own abstractions and also the knowledge of the sciences back into the whole of human experience of the world.

Hermeneutics raises consciousness about the influence of traditions or History on ones interpretative position and reflects on critical dimension. Criticism in the context according to Eisner, E.W (1998, P.3) is an art of saying useful things about complex and subtle objects and events so that others... Can see and understand what they did not see and understand before. In a nutshell, according to Eisner, the aim of critical approach in Hermeneutics is to illuminate a situation so that it can be seen or appreciated. This is achieved by the use of language. In support of critical approach of hermeneutics, Schott, R (1991, p.209) posits that a hermeneutic philosophy of interpretation must take on an 
overtly critical position. Quite convincing, Kearney, R (2003, p.187) aptly puts that critical hermeneutic approach affords a space for repressed voices to speak out and neglected text to get reading'. The role of history, context or location cannot be jettisoned in process of interpretation, the possibility of engaging a self-critical thinking consciousness and of transcending the insights of the present context are always present and key to attaining clear understanding of an object of interpretation.

\section{Conclusion}

Going by the fact that interpretation and meaning adduced by interpreters of various texts and events in history are often contradictory, it is inevitable to point that there should be process of producing a meaning and new knowledge by the aid of coherent, consistent and rational investigation. The complexity and interplay of various horizons that overlaps on ones consciousness in the process of hermeneutics makes the condition of understanding problematic.

It is on this problematic nature of process of understanding that makes the application of philosophical Hermeneutics of Gadamer necessary for attaining the true meaning of culture, tradition, text and other objects of philosophizing. In the course of this paper, we have posited that culture and tradition per se are non philosophy but with the mediation of Hermeneutics, African philosophy arises from African culture and tradition. Every philosopher is a representation of his background which gives rise to the foreground. In this vein, Gadamer posits that no philosophy is free from prejudice and not from a tradition. African philosophy evolved from peculiarity just as British, American and oriental philosophy. 
Since Hermeneutics as adduced by Heidegger is part and parcel of human ontology; no particular region of the world can be said to have existed without philosophy. It is the role of hermeneutics to get neglected text and traditions reading. Hence, hermeneutics is a bridge that linked African philosophy and culture and even philosophizing. Since interpretation is inherent in philosophizing. It is not rational for some thinkers to have said that ancient Africa was bereft of philosophy because their evidence of questioning and critical analysis was not documented. Their principles and intellectual postulation that add value to their existence were as a result of philosophizing which can only be intelligible to the present through philosophical hermeneutics.

\section{Ikechukwu Onah}

Department at Philosophy

University of Nigeria Nsukka kingsley.onah@unn.edu.ng 


\section{References}

Aja, E. (2015). Doing African Philosophy. Nsukka, Nigeria: University of Nigeria Press.

Bilen, O. (2000). The Historicity of Understanding \& Problem of Relativism in Gadamer's Philosophical Hermeneutics. Washington. USA: Library of congress cataloguing in publishing.

Eisner, E.W. (1998). The Enlightened Eye: Qualitative Inquiry and the Enhancement of Educational Practice, Upper saddle River, NJ.USA: Merrill.

Gadamer, H.G. (1996).Truth and Method 2nd Rev., ed., Joel Weinsheimer\& Donald Marshall Translation).New York. USA: Continuum.

Gadamer H.G. (1976).PhilosophicalHermeneutics (David E. Linge, ed and Trans). Berkeley, CA. USA: University of California Press.

Hooking, W.E. (1958).What is Philosophy" In Hooking W.E., types of philosophy. New York. USA: Charles Schribner.

Horton, R.(1967). African Traditional Thought \& Western Science.In Africa XXX VII Nos. 1 \& 2, (January and April, p.64).

Jardine D. (1999).To do well with boundless Heart: Essays in curriculum Theory, Hermeneutics and the Ecological Imagination. New York, USA: Peter Lang.

Jimbo, S.O.( 2002). An introduction to African philosophy Quoted in Njoku F.O.C., Essays in African philosophy, Thought \& Theology. Enugu. Nigeria: Snaap Press Ltd.

Kearney, R. (2003) Strangers, Gods and Monsters: Interpreting Otherness. London. England: Routledge. 
Niangoran - Bouah G. (1984) The Akan World of Gold Weights. Les Nouvelles Edition Africanines M.L. B, Abidjan. Vol 1, p.215.

Njoku, F. (2002). Essays in African philosophy, Thought \& Theology. Enugu. Nigeria: Snaap Press Ltd.

Oguejiofor, J. (2001).Philosophy and African Predicament.Ibadan. Nigeria: Hope Publications.

Okolo, C. (1993). African Philosophy: A short introduction. Enugu. Nigeria: Cecta Ltd.

Okonda, O.(1991). "Traditions \& Destiny". Horizons of an African philosophical hermeneutics in African philosophy: The Essential Readings (ed) in TsenaySerequeberhan .New York. USA: Paragon House,p.202

Schott R. (1991). Whose Home is It Anyway? A feminist response to Gadamer's Hermeneutics.In Hugh Silverman (ed), Gadamer and Hermeneutics. New York. USA: Rutledge.

Schwandt, T. (2001) Hermeneutics Circle in Dictionary of Qualitative Inquiry. Thousand Oaks, CA. USA: Sage Publication.

Wachterhauser B. (1986). Hermeneutics and Modern Philosophy (ed) Albany, NY. USA: State University Press. 